\title{
O artykule naukowym słów kilka
}

Ewa Bulisz | Wydział Humanistyczny UMCS w Lublinie

Streszczenie

Słowa kluczowe:

artykuł naukowy, gatunek,

genologia, model opisu gatunku,

Maria Wojtak

academic article,

genre,

genology,

model of genre

description,

Maria Wojtak

Autorka na podstawie literatury przedmiotu przybliża najważniejsze wyznaczniki genologiczne artykułu naukowego, przywołując dotychczasowe ustalenia dotyczące jego struktury, potencjału poznawczego oraz pragmatycznych i stylistycznych uwikłań. Opracowanie ma charakter przeglądowy. Dla młodego badacza niniejszy szkic może mieć także charakter dydaktyczny.

\section{A Few Words about a Scientific Article}

\section{Abstract}

On the basis of literature, the author gives a broad outline of the most important genologic indicators of the academic article. There are evoked existing findings, concerning structure, cognitive potential, pragmatic and stylistic entanglement of the academic article, in the text. The research paper is of demonstration character. For the young researcher the present text may have also didactic value. 


\section{Wprowadzenie}

Wśród gatunków mowy przynależnych do dyskursu naukowego szczególnie uprzywilejowane miejsce zajmuje artykuł naukowy. Uznaje się go za elementarny' sposób komunikacji pomiędzy naukowcami na całym świecie. Służy on utrwalaniu i upowszechnianiu nowej i oryginalnej wiedzy, uzyskanej w rezultacie prowadzonych badań.

Bez względu na to, czy artykuł dotyczy nauk medycznych, przyrodniczych, ścisłych lub humanistycznych, musi zostać opracowany pod względem merytorycznym, a ze względu na pisemny charakter - także stylistycznym i edytorskim. Przygotowanie artykułu naukowego wymaga nie tylko specjalistycznej wiedzy z określonej dyscypliny, ale także umiejętności jasnego formułowania wypowiedzi, argumentacji i wnioskowania. Dla młodych badaczy, do których grona siebie także włączam, napisanie artykułu naukowego stanowi poważne wyzwanie. Jednakże pisanie jest działaniem językowym, które kształtujemy poprzez nieustanną praktykę i doskonalenie własnego warsztatu.

Odpowiednio przygotowany artykuł naukowy powinien mieć wyraźnie wskazany cel, przedmiot badań oraz metodologię. Wybór metody wyznacza określoną drogę poznawczo-komunikacyjną i sposób poruszania się po niej. Zastosowanie wybranej metodologii pozwala zaprezentować autorowi analizy i wnioski, natomiast innym badaczom (odbiorcom tekstu) pomaga sprawnie przyswoić nową wiedzę, zweryfikować wyniki lub też podjąć polemikę z autorem tekstu.

W dotychczasowej literaturze przedmiotu znajdziemy wiele opracowań poświęconych tekstom naukowym, głównie stylowi naukowemu (Gajda 1982; 1990; 2012), zagadnieniom warsztatowym (Maćkiewicz 1996; Trzynadlowski 1983; Stępień 2016), edytorskim (Wolański 2008) oraz leksyce wybranych dyscyplin naukowych (Biniewicz 2002; Dąbkowski 1997, 2010; Podobiński 1997). Dokonując prezentacji najważniejszych aspektów artykułu naukowego, chcę zasygnalizować tylko najważniejsze jego wyznaczniki, gdyż szczegóły zostały już wyczerpująco omówione przez wymienionych badaczy.

Wykorzystując instrumentarium pojęciowe Marii Wojtak i zaproponowany przez badaczkę czteroaspektowy model opisu gatunku (Wojtak 1999: 105-107; 2004), postaram się $w$ tym szkicu przybliżyć najważniejsze ustalenia związane $z$ artykułem naukowym i jego strukturalnymi, pragmatycznymi, poznawczymi i stylistycznymi wyznacznikami. Niniejsze opracowanie ma charakter przeglądowy.

\footnotetext{
1 "Odpowiednikiem” artykułu naukowego w mówionej odmianie języka jest referat, najczęściej przygotowywany z myślą o wystąpieniu na konferencji naukowej. Referat, chociaż zbliżony do artykułu naukowego, jest tekstem, który powinien uwzględniać inny sposób percepcji przez odbiorcę. Pomiędzy artykułem naukowym a referatem można dostrzec relacje adaptacyjne. Te kwestie pozostawiam jednak na oddzielne omówienie.
} 


\section{Aspekt strukturalny artykułu naukowego}

Mówiąc o strukturze artykułu naukowego, należy wyodrębnić jego elementy paratekstowe, czyli teksty poboczne, do których należą: tytuł, dane autora (imię i nazwisko, tytuł naukowy, afiliowana jednostka naukowa, dane kontaktowe, nota personalna/biogram naukowy), słowa klucze, abstrakt, streszczenie, indeks nazwisk i przypisy. Streszczenia oraz słowa klucze najczęściej powinny zostać przywołane także w języku angielskim lub innym wskazanym przez redakcję języku kongresowym².

Do każdego artykułu naukowego obligatoryjnie dołącza się bibliografię prac naukowych, które posłużyły w prezentacji dotychczasowego stanu wiedzy bądź zostały zacytowane w tekście. Przestrzegając praw autorskich i szanując własność intelektualną innych badaczy, należy wyraźnie wyodrębniać segmenty własnych wypowiedzi od segmentów przywołanych (cudzych, obcych wypowiedzi).

Ustawa o prawie autorskim i prawach pokrewnych stwierdza, że wolno przytaczać w utworach stanowiących samoistną całość urywki rozpowszechnionych utworów lub drobne utwory w całości w zakresie uzasadnionym wyjaśnieniem, analizą krytyczną, nauczaniem lub prawami gatunku twórczości (Wolański 2008: 198).

Cytaty zapisujemy najczęściej w cudzysłowie lub wyróżniamy odpowiednią wielkością czcionki i wcięciem akapitowym. Szczegóły określające sposób sporządzania przypisów i bibliografii są ustalane przez redakcję i najczęściej zamieszczone na oficjalnej stronie czasopisma. Redaktorzy, biorąc pod uwagę funkcje, jakie ma pełnić bibliografia, decydują o tym, które elementy opisu bibliograficznego są obligatoryjne, a które należy pominąć (na przykład nazwę wydawnictwa, miejsce wydania, rok wydania, numer tomu i/lub zeszytu, rocznika, datę dostępu, liczbę stron i tak dalej). Niedostosowanie tekstu do wymogów formalnych może skutkować niedopuszczeniem go do dalszej procedury recenzowania i zostaje on odrzucony już na wstępnym etapie. Warto pamiętać, że to na autorze spoczywa obowiązek dołączenia do artykułu wszystkich obligatoryjnych segmentów.

Fakultatywne składniki artykułu naukowego to elementy pomocne w prezentacji wywodu, między innymi: tabele, wykresy, schematy, diagramy, ilustracje, mapy, infografiki, tablice historyczne i genologiczne (Wolański 2008: 210-233).

Przyglądając się architektonice artykułu naukowego, należy dostrzec także jego wewnętrzne rozczłonkowanie na akapity, punkty lub zbiory akapitów, oddzielone śródtytułami. Delimitacja tekstu ułatwiać ma odbiorcy tok rozumowania autora. Porządek strukturalny powinien odzwierciedlać proces dochodzenia od hipotezy do konkluzji. Jak dostrzegł Emanuel Kulczycki, w naukach humanistycznych „proces pisania jest niejednokrotnie tożsamy z procesem prowadzenia badań" (Kulczycki 2014: 118).

2 Za języki kongresowe uznano: angielski, rosyjski, francuski, niemiecki, hiszpański i włoski. Liczba opublikowanych artykułów we wskazanych językach (choć nie tylko!) świadczy o stopniu umiędzynarodowienia czasopisma. 
Przed przystąpieniem do pisania warto przygotować plan artykułu. Zapewni to spójność logiczną między poszczególnymi akapitami i rozwijanymi myślami. Jolanta Maćkiewicz wskazuje, że „istnieje pewna prawidłowość: im więcej czasu poświęci się na opracowanie schematu [planu artykułu - przyp. E.B.], tym mniej się go straci przy pisaniu" (Maćkiewicz 1996: 38). Badaczka pisanie artykułu dzieli na trzy zasadnicze fazy: działania przygotowawcze, pisanie tekstu oraz poprawianie i przeredagowywanie tekstu (1996: 38). Prace przygotowawcze związane są z gromadzeniem, analizowaniem oraz porządkowaniem materiałów badawczych i obejmują kilka kroków:

1. Analiza tematu ogólnego.

2. Wybór tematu szczegółowego.

3. Sformułowanie tezy pracy.

4. Zbieranie materiału [...].

5. Sporządzanie planu roboczego (Maćkiewicz 1996: 44).

W trosce o ułatwienie czytelnikowi odbioru tekstu kompozycja artykułu naukowego powinna zostać przemyślana i starannie opracowana. Podział tekstu na trzy części - początek (wstęp, wprowadzenie), środek (analiza, argumentacja, dowodzenie, dedukcja) oraz koniec (podsumowanie, wnioski) - stanowi podstawowy sposób uporządkowania treści. Odpowiednie segmentowanie tekstu na akapity pozwala odbiorcy w sposób uporządkowany przyswajać kolejne tezy:

[...] dobry akapit powinien być na tyle długi, aby wyrazić jedną myśl i rozwinąć ją w sposób wystarczający dla celów nadawcy i na tyle krótki, aby ułatwić czytelnikowi odbiór tekstu. Powinien być to zatem kawałek jednocześnie pożywny i strawny (Maćkiewicz 1996: 77).

Akapit inicjalny pełni szczególnie istotną funkcję. Po pierwsze, wprowadza w przedmiot, problematykę i cel badań. Po drugie, może decydować o pozyskaniu zainteresowania odbiorcy. Ważnym elementem kompozycyjnym jest także akapit finalny. Nie zawsze wprowadzenie i zakończenie ogranicza się do jednego akapitu. Najczęściej części te mają nieostro zarysowane granice. Do funkcji, które pełnią wprowadzenie i zakończenie, powrócę w dalszej części artykułu.

\section{Aspekt pragmatyczny artykułu naukowego}

W szerokim znaczeniu pragmatyka lingwistyczna podejmuje zagadnienia związane z komunikacyjnymi uwikłaniami użycia języka (Polański, red., 2003: 453-454). Biorąc pod uwagę pragmatyczne aspekty artykułu naukowego, należy dookreślić nadawcę, odbiorcę, relację między nadawcą i odbiorcą, funkcje i cele komunikatu oraz kontekst sytuacyjny.

W artykule naukowym mamy do czynienia z "komunikacją, którą charakteryzuje elitaryzm" (Wojtak 2015: 65), to znaczy artykuł skierowany jest do określonych odbiorców. Łączy ich wspólnota wiedzy i zainteresowań, ujęta przez Wojtak w formule 
„SWoi mówią do swoich, entuzjaści komunikują się z entuzjastami" (Wojtak 2015: 65). Pomiędzy nadawcą artykułu a jego odbiorcami istnieje wiedza wspólna, która pozwala na stosowanie specjalistycznych terminów i pojęć ułatwiających swobodne poruszanie się w obrębie jednej dyscypliny. Każda gałąź nauki wypracowała własne instrumentarium pojęciowe, a posługiwanie się nim służy precyzyjnej i ekonomicznej komunikacji pomiędzy naukowcami.

Główną funkcją artykułu naukowego jest funkcja informująca ${ }^{3}$. Uwzględniając teorię aktów mowy, artykuł naukowy jest aktem asercji, czyli oznajmiania. Intencją nadawcy jest zbudowanie tekstu, który w sposób spójny przekazuje materiał myślowy.

Zaproszeniem do lektury jest - wspomniane już - wprowadzenie do artykułu naukowego. Można wykorzystać różne sposoby nawiązania komunikacji z odbiorcą. Najważniejsze jest przede wszystkim wyraźne wskazanie, co będzie przedmiotem badań w podjętym artykule naukowym:

Celem mojej (tej) pracy jest...

W artykule (szkicu) będę się zajmować...

Artykuł jest poświęcony...

Jako temat artykułu wybieram..., ponieważ...

W pierwszej części będę mówić o...

Rozpocznę od..., następnie... itp. (Maćkiewicz 1996, 102).

Spójność w artykule zostaje utrzymywana także dzięki wypowiedziom o charakterze metatekstowym i porządkującym komunikat, na przykład: "jak już wspomniano", "jak była mowa”, ,o tym w dalszej części”, „podsumowując”, „konkludując”, „w zakończeniu", "we wnioskach" $i$ tak dalej. Zwroty te organizują tekst pod względem formalnym i semantycznym, służąc odbiorcy jako sygnały wyznaczające początek lub koniec tekstu. W zakończeniu można przyjmować różne strategie komunikacyjne:

- doprecyzować postawioną na początku tezę,

- podsumować przeprowadzone analizy i wyciągnąć wnioski,

- podjąć dyskusję,

- streścić artykuł,

- uzasadnić argumentację,

- wyjaśnić problem,

- zaproponować autorską tezę,

- zaproponować dalsze badania i kierunki badań.

${ }^{3} \mathrm{Nie}$ oznacza to, że inne funkcje nie występują w artykule naukowym. Funkcja informacyjna jest jednak dominująca w stosunku do funkcji impresywnych czy estetycznych, których także można doszukiwać się w artykule tego typu.. 
Zakończenie powinno nawiązywać do zaproponowanych lub zadeklarowanych we wstępie tez i/lub hipotez. Dążeniem autora artykułu naukowego jest skłonienie odbiorcy do refleksji nad przedstawionym zagadnieniem. Podjęcie przez odbiorcę polemiki z postawionymi $w$ artykule tezami nie ujmuje wartości ani artykułowi, ani samemu autorowi artykułu. Nauka bowiem ma charakter kumulatywny, a przyświecającym jej celem jest dążenie do poznania wiedzy uniwersalnej i obiektywnej.

\section{Aspekt poznawczy artykułu naukowego}

Biorąc pod uwagę liczbę dziedzin naukowych, dyscyplin oraz nurtów, aspekt poznawczy artykułu naukowego obejmuje tak szeroki zakres tematyczny, że jestem zmuszona zrezygnować ze szczegółowego jego omawiania i skupić uwagę na charakterystyce tych problemów, które mieszczą się w rozmiarach niniejszego opracowania.

Świat przedstawiony w naukowym dyskursie zakłada stałe pozyskiwanie nowej wiedzy i nieustanne dążenie do jej pogłębiania. Twórca artykułu naukowego jest podmiotem zarówno poznającym świat, jak i prezentującym rezultaty tego poznania (Gajda 2012: 183), sam artykuł naukowy stanowi zaś nośnik tej wiedzy. Problematyka artykułu jest zawsze bezpośrednio związana z dyscypliną, w której nurcie zostają podjęte badania. Autor artykułu dobiera temat, zakreśla przedmiot swoich badań oraz wybiera ścieżkę interpretacyjną.

Obecnie w różnych dyscyplinach naukowych można dostrzec wyraźny proces rozłamu głównych dziedzin na coraz to węższe kierunki, szkoły czy paradygmaty. Młody naukowiec, który dopiero zdobywa praktykę analityczną, powinien starać się spojrzeć na przedmiot swoich badań zarówno z dalszej, jak i bliższej perspektywy, szukając swojego miejsca w wybranym obszarze nauki.

Z aspektem poznawczym wiąże się aspekt aksjologiczny. Naturalnym oczekiwaniem odbiorcy wobec nadawcy artykułu naukowego jest przestrzeganie zasad etyki. Wartości, którymi powinien kierować się autor, to przede wszystkim „prawda, racjonalizm i obiektywizm" (Gajda 2003: 62). Ważne, aby w praktyce naukowej starać się dążyć do ideałów, które przyświecają profesji naukowca:

W praktyce naukowej obserwuje się, że naukowcy mają rozeznanie co do "wartości naczelnych", ale nie zawsze są skłonni zachowywać się zgodnie z nimi. W rolę współczesnego naukowca wpisane są normy i antynormy dotyczące jego zachowania się jako podmiotu poznającego ( $m$.in. związane z wyborem profesji badacza, dziedziny i tematu badań, metod) jako członka społeczności naukowej (m.in. odnoszące się do etyki publikacji i dyskusji naukowej) oraz jako kierownika i recenzenta (kontrolera) (Gajda 2012: 185).

Artykuł naukowy jest wyjątkowym tworem materialnym o istotnym znaczeniu dla całego społeczeństwa. Jako nośnik wiedzy jest najlepszym świadectwem rozwoju nauki, dlatego tak ważny jest aksjologiczny charakter tekstów naukowych. 
Przyjęty przez nadawcę artykułu naukowego punkt widzenia powinien zakładać obiektywność, która polega na braku emocjonalności, a także dążeniu do ścisłości w ujmowaniu badanej rzeczywistości. Nie zawsze jest jednak to możliwe (Pałucka 2000). Każdy artykuł naukowy (w tym także teoretyczny czy przeglądowy) niesie za sobą wartość dydaktyczną, dlatego badacze często w sposób obrazowy starają się przedstawić rezultaty swoich dociekań. Najczęściej wykorzystują przy tym analogie i porównania, które w obrazowy sposób ujmują naukową płaszczyznę badawczą.

\section{Aspekt stylistyczny artykułu naukowego}

Pisząc artykuł naukowy, należy stale mieć na uwadze potencjalnego odbiorcę i używać takich wyrazów i konstrukcji zdaniowych, które rzetelnie przekażą nasze myśli oraz intencje. Poprawne i sprawne komunikowanie, wolne od błędów językowych i zgodne z przyjętymi normami, ma nie mniejsze znaczenie niż wiedza i zainteresowania łączące nadawcę i odbiorcę. Zrozumiały i interesujący artykuł naukowy daje szansę na zaangażowanie się odbiorcy oraz podjęcie dyskusji.

Poczucie językowe często sprowadza się do przekonania, że należy mówić i pisać „uczenie", a więc językiem „twardym”. Wynikać ono może z przyjęcia określonej tradycji pisarstwa naukowego. Czasami o wyborze tej maniery wykładu decyduje chęć stworzenia pozorów naukowości albo - co gorsza - postawienie bariery uniemożliwiającej kontrolę poprawności rozumowania autora i wówczas nie jest to tylko kwestia kultury języka, ale także kwestia „moralności” (Gajda 2012: 194).

To właśnie język jest podstawowym narzędziem porozumiewania się i nośnikiem wiedzy. Nie sposób zatem zbudować zrozumiałego tekstu naukowego bez umiejętności sprawnego posługiwania się językiem.

Jeżeli nauka dąży racjonalną drogą do poznania świata, do wiedzy prawdziwej, to pytanie o świat jest równocześnie pytaniem o stosunek między światem a ludzkim myśleniem, natomiast dociekania nad myślą prowadzą do rozważań nad językiem (Gajda 2003: 63).

Artykuł naukowy należy do tekstów oficjalnych i powinien spełniać wyznaczniki typowe dla stylu naukowego, co nie oznacza, że należy rezygnować z indywidualnego charakteru pisania. Badaczom o bogatym dorobku naukowym poprzez wieloletnią praktykę pisania udaje się wypracować własny styl. W fazie początkowej szlifowania umiejętności pisania warto szukać wzorcowych realizacji stylistyczno-językowych wśród autorytetów w swojej dyscyplinie naukowej i naukach pokrewnych.

Autor artykułu naukowego powinien starać się obiektywnie powiadamiać o własnych wynikach badań i odwoływać się do wiedzy, która już została upowszechniona przez innych badaczy. Przywoływanie cudzych wypowiedzi sprawia, że że w artykule naukowym mamy do czynienia z wielogłosowością ${ }^{4}$.

${ }^{4}$ Wielogłosowość - termin genologiczny wprowadzony przez Wojtak dla określenia zjawiska występowania w jednym tekście/gatunku głosów różnych osób (Wojtak 2015). 
Operacje myślowe - takie jak argumentacja, dowodzenie własnego stanowiska czy wnioskowane - powinny przebiegać w sposób logiczny i uporządkowany. Służy temu używanie terminów i pojęć z określonej dyscypliny. Jak zauważa Gajda, mogą one stanowić około 20-30\% użytych leksemów (Gajda 2012: 185). Dla stylu naukowego charakterystyczna jest także składnia, która ujawnia preferowanie przez naukowców głównie rzeczowników i przymiotników jako słów nośnych informacyjnie. Konkretyzacji i ścisłości w przedstawianiu wywodu służyć mogą symbole, skróty, wzory, a także tabele, wykresy czy schematy. Należy unikać abstrakcyjnego i emocjonalnego argumentowania własnego stanowiska.

Kryteria doboru artykułów, które mogłyby służyć jako wzorcowe, powinny uwzględniać autorytet badacza. Osoby będące na początku ścieżki naukowej najczęściej ukrywają się za formami bezosobowymi. Naukowcy cieszący się uznaniem w środowisku naukowym odważniej stawiają tezy, co wynika także z wieloletniego doświadczenia i wypracowania ugruntowanych poglądów. Niewątpliwie najlepszym sposobem uczenia się pisania artykułów jest praktyka i czytanie artykułów swoich mistrzów.

\section{Podsumowanie}

Mobilność wiedzy w globalizującym się świecie powoduje, że redakcje czasopism naukowych zaczęły wypracowywać wspólne standardy dotyczące budowy artykułu naukowego oraz wymogów edytorskich. W ocenie parametryzacyjnej ważne jest przygotowanie tekstu w jednym z języków kongresowych oraz umiędzynarodowienie recenzentów i rady naukowej. W obecnym kształcie ocena parametryzacyjna jest szczególnie krzywdząca dla nauk humanistycznych (Kulczycki 2014: 117-140). W Polsce dopiero od kilku lat wypracowywany jest system oceny prac naukowych. Obrany kierunek to - niestety - „proces przesuwania akcentów z «treści naukowej» na «miejsce opublikowania»" (2014: 120). Ocena jakości artykułu jest zatem obecnie zależna od czasopisma i/lub monografii, w której został on opublikowany. Redakcje czasopism, zabiegając o jak najwyższą ocenę (punkty), muszą spełnić określone kryteria i stosować ustalone procedury kwalifikacji publikacji do druku.

Ważne, żeby w dobie „punktyzacji” młodzi badacze pamiętali, że funkcją artykułu naukowego jest przede wszystkim utrwalanie i upowszechnianie wiedzy w sposób komunikatywny. Znajomość wyznaczników kanonicznego wzorca artykułu naukowego należy do kompetencji niezbędnych w pracy badacza-naukowca, szczególnie dopiero zaczynającego stawiać pierwsze kroki w dyskursie naukowym.

Uwzględniając perspektywę kompozycyjną, pragmatyczną, poznawczą i stylistyczną, należy dołożyć starań, aby wszystkie komponenty artykułu naukowego tworzyły uporządkowaną i kompletną całość zarówno pod względem formalnym, semantycznym, jak i logicznym. 


\section{Literatura}

Biniewicz J., 2002, Kształtowanie się polskiego języka nauk matematyczno-przyrodniczych, Opole: Wydawnictwo Uniwersytetu Opolskiego.

Dąbkowski G., 1997, Europejska terminologia muzyczna, Kielce: Wyższa Szkoła Pedagogiczna im. Jana Kochanowskiego.

Dąbkowski G., 2010, Kształtowanie się polskiej terminologii muzycznej, Warszawa: ASPRA-JR.

Gajda S., 1982, Podstawy badań stylistycznych nad językiem naukowym, Warszawa-Wrocław: PWN.

Gajda S., 1990, Współczesna polszczyzna naukowa - język czy żargon?, Opole: Wydawnictwo Instytutu Śląskiego.

Gajda S., 2003, Styl naukowy [w:] Przewodnik po stylistyce polskiej, red. E. Malinowska, J. Nocoń, U. Żydek-Bednarczuk, Kraków: Universitas.

Gajda S., 2012, Styl naukowy [w:] Współczesny język polski, red. J. Bartmiński, Lublin: Wydawnictwo Uniwersytetu Marii Curie-Skłodowskiej.

Kulczycki E., 2014, Zasady oceny czasopism humanistycznych i ich rola w parametryzacji jednostek naukowych, "Nauka”, nr 3.

Maćkiewicz J., 1996, Jak pisać teksty naukowe?, Gdańsk: Wydawnictwo Uniwersytetu Gdańskiego.

Pałucka I., 2000, O bezemocjonalności wybranych tekstów naukowych (rekonesans badawczy) [w:] Gatunki mowy i ich ewolucja, t. 1: Mowy piękno wielorakie, red. D. Ostaszewska, Katowice: Wydawnictwo Uniwersytetu Śląskiego.

Podobiński S., 1997, Kształtowanie się polskiej terminologii rolniczej, Częstochowa-Kraków: Wydawnictwo Wyższej Szkoły Pedagogicznej w Częstochowie.

Polański K. (red.), 2003, Encyklopedia językoznawstwa ogólnego, oprac. M. Jurkowski et al., Wrocław: Zakład Narodowy im. Ossolińskich.

Stępień B., 2016, Zasady pisania tekstów naukowych. Prace doktorskie i artykuły, Warszawa: Wydawnictwo Naukowe PWN.

Trzynadlowski J., 1983, Edytorstwo. Tekst, język, opracowanie, Warszawa: Wydawnictwa Naukowo-Techniczne.

Wojtak M., 1999, Wyznaczniki gatunku wypowiedzi na przykładzie tekstów modlitewnych, „Stylistyka", t. 8.

Wojtak M., 2004, Gatunki prasowe, Lublin: Wydawnictwo Uniwersytetu Marii Curie-Skłodowskiej.

Wojtak M., 2015, Rozłożone gazety. Studia z zakresu prasowego dyskursu języka i stylu, Lublin: Wydawnictwo Uniwersytetu Marii Curie-Skłodowskiej.

Wolański A., 2008, Edycja tekstów. Praktyczny poradnik. Książka, prasa, www, oprac. red. L. Wiśniakowska, Warszawa: Wydawnictwo Naukowe PWN. 